\title{
What is happening in the European hotel sector?
}

Received: 5 October 2004

\section{Ruth Waite}

is a research analyst with the London office of HVS International, a leading global firm of hotel real estate advisers and valuers.

\section{Russell Kett}

is Managing Director of the London office of HVS International, which covers Europe, the Middle East and Africa, and each year advises on some 250-300 individual hotels or developments within the Europe, Middle East and Africa region.

\section{Abstract}

The authors are delighted to introduce a series of quarterly papers which aim to observe the latest trends in the key industry sectors. Subjects to be covered in forthcoming issues will be boutique/lifestyle hotels, budget hotels, luxury hotels, mid-market hotels, serviced apartments and timeshare/resort developments. This first paper in the series presents a snapshot of current trends in the market generally concerning values, acquisitions and disposals, funding and development, and includes highlights of recent events from the year so far.

\section{Keywords:}

European RevPAR, hotel values, hotel investment activity, hotel funding trends

\section{INTRODUCTION}

Since the beginning of 2004, the long awaited revenue per available room (RevPAR) growth in Europe has been a gradual and muted affair, but industry experts are at last reporting with more optimism on the progress being made. In the current climate of volume-led recovery, where additional variable costs are associated with servicing more rooms and guests, it is only those hotel markets that are able to increase average rates as well as occupancy that are enjoying marked improvements in revenues.

According to Deloitte, ${ }^{1}$ the majority of countries in Europe have experienced an improvement in occupancy during recent months. The year-to-date occupancy percentage for Europe in September 2004 compared with the same period in 2003 was up by 3.7 per cent from 63.8 per cent to 66.2 per cent. The increased demand for hotel accommodation, which is indicated by growing occupancy percentages across most of Europe, will inevitably lead to a much 
For the most part, it is expected to be 2005 before many markets experience strong average rate growth recovery.

Considering the adverse conditions endured by the industry globally since 2001, UK hotels have remained one of the most efficient markets at converting revenues to profit. Due to its comparably strong economy and low payroll to revenue ratios within Europe, the UK has been able to capitalise on the resurgence in both leisure and corporate travel, which has largely been driven by London.

While European markets have continued to be affected by the decrease in international tourism arrivals, recent months have shown significant growth in visitor numbers from key markets such as the USA and Japan, despite the appreciation of the euro and the pound against the dollar.

\section{VALUES}

HVS International's European Hotel Valuation Index (HVI) ${ }^{2}$ for 2003 showed that hotel values across Europe dipped by 4 per cent on average. In fact, 2003 marked the third consecutive year of declines in hotel values since the golden year of 2000, when growth was still surging ahead at 11 per cent across Europe.

In 2003, only four of the 28 markets tracked by the HVI recorded growth in value per room in euro returns. Moscow recorded the highest growth in value per room with an increase of 9 per cent. In those markets showing a decline, Budapest recorded the most significant decrease in value per room at 14 per cent (see Figure 1).

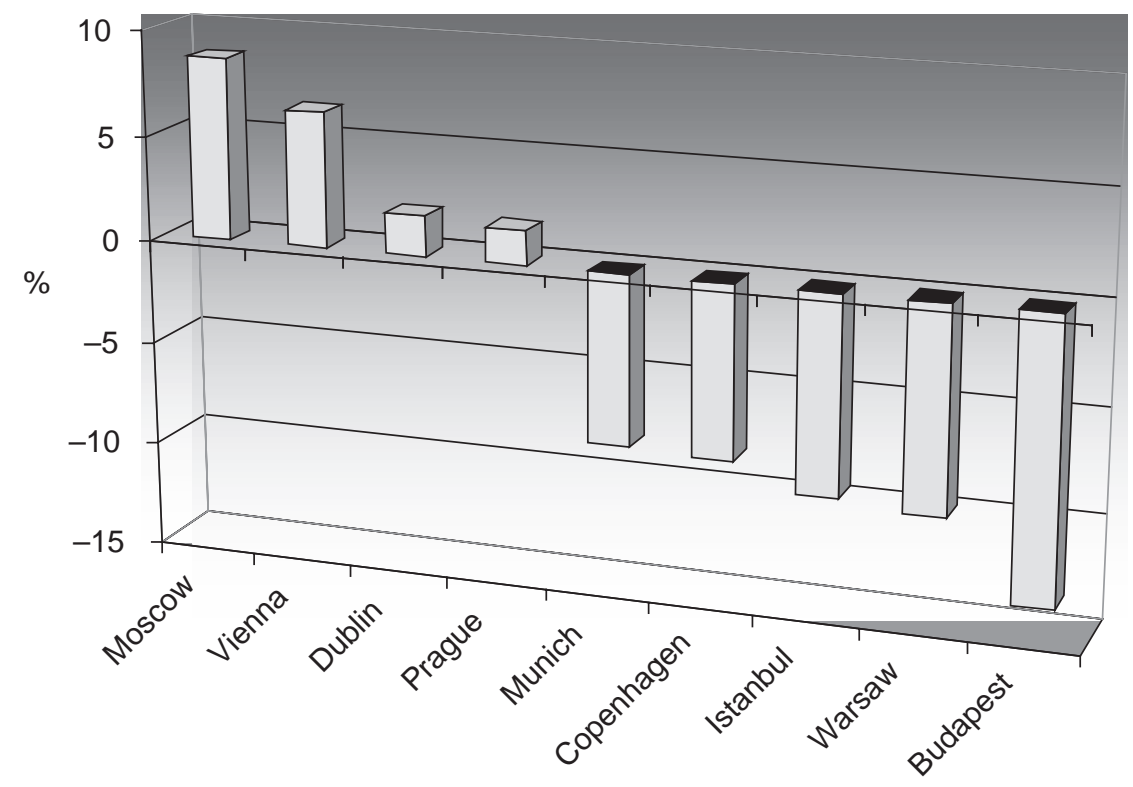

Figure 1: Winners and losers in 2003 - Percentage change in hotel values 
While continental Europe's hotels mainly recorded declines in value in 2003, the strength of the pound meant that hotel values in UK cities, in sterling terms, rose in Birmingham, Edinburgh, Manchester and London by 5 per cent, 6.5 per cent, 4 per cent and 4 per cent respectively.

Although the continued threat of global terrorism makes the outlook for the future of hotel values somewhat uncertain, especially in key gateway cities, the hotel market has already priced in this likelihood to a large extent. With hotel operating performances tentatively making steps towards recovery, this should ultimately act as a catalyst for growth in values.

With the growth in demand for hotel accommodation leading to improved occupancy, average room rates and thus RevPAR, one can expect to see the recovery in hotel values that has begun in 2004 continuing well into 2005 and beyond. This is likely to be most noticeable in London and other international gateway cities to begin with, followed by more secondary locations.

\section{ACQUISITIONS AND DISPOSALS}

While portfolio investment activity in 2003 remained at a significantly low level $(€ 3.5 \mathrm{bn})$ compared to the unprecedented volumes seen in 2001 ( $€ 8.8 \mathrm{bn})$, overall hotel property deals struck in Europe and tracked by HVS International ${ }^{3}$ rose by 21 per cent on 2002 levels to $€ 6.6 \mathrm{bn}$. This is due, in part, to single-asset investment activity increasing despite volatile hotel trading conditions. In fact the investment performance achieved for single assets of approximately $€ 3.1$ bn was just 3 per cent below the record high of around $€ 3.2 \mathrm{bn}$ in 2001. See Figure 2.

In 2003 single-asset transactions equated to 47 per cent of the total investment activity. Noteworthy single-asset transactions included the 167-room Ritz Hotel in Madrid sold to Orient Express and Omega Capital for approximately $€ 125 \mathrm{~m}$ ( $€ 749,000$ per room)

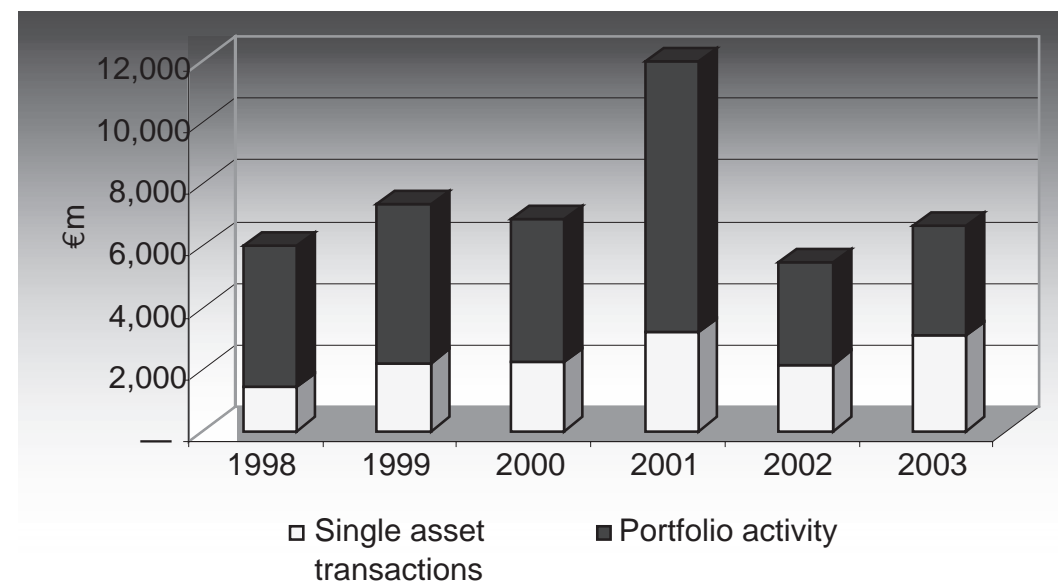

Figure 2: Total hotel investment volumes 1998-2003 
and the 404-room Principe de Savoia Hotel in Milan sold to the Dorchester Group for around $€ 275 \mathrm{~m}$ ( $€ 681,000$ per room).

Significant portfolio transactions in 2003 included the disposal of 37 Thistle-managed hotels by Orb Estates to investment vehicle Atlantic Hotels for approximately $€ 990 \mathrm{~m}(€ 181,000$ per room) and Whitbread's sale of 13 Swallow properties to REIT Asset Management for $€ 74 \mathrm{~m}$ ( $€ 64,000$ per room).

Although RevPAR performances have been gradually improving in many European markets during 2004, single-asset transaction activity does not appear to have changed pace considerably. Furthermore, portfolio and corporate activity in 2004 has remained at comparably depressed levels in the years following the record year of 2001. Although increased levels of activity in 2003 confirmed the general consensus that hotel markets are opening up again, it would also be fair to comment that developments in investment activity are unlikely to be immediate in effect or significant in nature.

Table I: Selected European single-asset hotel transactions 2004

\begin{tabular}{|c|c|c|c|c|c|c|c|}
\hline Property & City & Country & Rooms & $\begin{array}{l}\text { Sale price } \\
\boldsymbol{\epsilon}\end{array}$ & $\begin{array}{l}\text { Sale price } \\
\text { per room } €\end{array}$ & Buyer & Seller \\
\hline Excelsior Hotel & Dubrovnik & Croatia & 164 & $35,260,000$ & 215,000 & Wren's Hotel Group & Undisclosed \\
\hline Sofitel Demeure Marignon & Paris & France & 73 & $27,500,000$ & 376,700 & Private Investor & $\mathrm{ABC}$ \\
\hline $\begin{array}{l}\text { Balzac Hotel \& de Vigny } \\
\text { Hotel }\end{array}$ & Paris & France & 107 & $53,500,000$ & 500,000 & $\begin{array}{l}\text { JJW Hotels \& Resorts } \\
\text { \& ME Investor }\end{array}$ & Pacific Investment plc \\
\hline Jurys Limerick Hotel & Galway & Ireland & 95 & $9,750,000$ & 102,600 & Danesfield Ltd & Jurys Doyle \\
\hline Jurys Inn Christchurch & Dublin & Ireland & 185 & $9,000,000$ & 48,600 & Jurys Doyle & Not in the public domain \\
\hline The Castletroy Park Hotel & Limerick & Ireland & 107 & $25,000,000$ & 233,600 & Private Investor & Mr Chuck Feeney \\
\hline Portimao Marina Hotel & Algarve & Portugal & 196 & $14,000,000$ & 71,400 & Espirito Santo Hotel Group & Not in the public domain \\
\hline Sol Aloha Playa & Malaga & Spain & 172 & $16,584,200$ & 96,400 & Not in the public domain & Sol Melia \\
\hline Torrequebrada & Malaga & Spain & 350 & $43,600,000$ & 124,600 & Private Investor & $\begin{array}{l}\text { Asesoramiento y Direccion } \\
\text { de Hoteles }\end{array}$ \\
\hline First Hotel G & Gothenburg & Sweden & 305 & $27,000,000$ & 88,500 & Host Hoteleiendom & $\begin{array}{r}\text { NCC Property } \\
\text { Development }\end{array}$ \\
\hline Le Richemond Hotel & Geneva & Switzerland & 98 & $66,000,000$ & 673,500 & Rocco Forte Luxury Hotels & $\begin{array}{l}\text { Richemond Hotel Holdings } \\
\text { SA }\end{array}$ \\
\hline Moat House Edinburgh & Edinburgh & UK & 111 & $7,757,800$ & 69,900 & $\begin{array}{l}\text { Hotel Property Fund } \\
\text { (Portland Hotels) }\end{array}$ & Queens Moat House \\
\hline Midland Hotel & Manchester & UK & 303 & $53,871,100$ & 177,800 & Quintessential Hotels & InterContinental Hotels \\
\hline Drury Lane Moat House & London & UK & 163 & $16,393,600$ & 100,600 & $\begin{array}{l}\text { TLLC Group Holdings - } \\
\text { Travelodge }\end{array}$ & Queens Moat House \\
\hline Caesar Hotel & London & UK & 160 & $30,110,200$ & 188,200 & $\begin{array}{l}\text { Derby Hotels \& Metropolis } \\
\text { Investment Group }\end{array}$ & Not in the public domain \\
\hline Days Inn & London & UK & 160 & $21,077,100$ & 131,700 & Private Investor & Quercus Fund \\
\hline $\begin{array}{l}\text { Radisson SAS Hotel } \\
\text { Manchester Airport }\end{array}$ & Manchester & UK & 360 & $75,343,000$ & 209,300 & DIFA German Fund & Rezidor SAS \\
\hline Express by Holiday Inn & Stansted Airport & UK & 255 & $10,924,700$ & 42,800 & BAA's Hotels Partnership & Undisclosed \\
\hline Sloane Square Moat House & London & UK & 105 & $18,609,700$ & 177,200 & Sloane Square Hotel Ltd & QMH Hotels \\
\hline Quality Hotel Kensington & London & UK & 72 & $10,517,400$ & 146,100 & Western Heritable & $\begin{array}{l}\text { International Currency } \\
\text { Exchange }\end{array}$ \\
\hline Holiday Inn Gatwick & Crawley & UK & 217 & Undisclosed & & Not in the public domain & InterContinental Hotels \\
\hline Days Hotel Derby & Derby & UK & 100 & $8,564,100$ & 85,600 & GSC Property Holdings & Undisclosed \\
\hline Ramada Jarvis Kensington & London & UK & 82 & $18,781,000$ & 229,000 & Not in the public domain & Jarvis Hotels \\
\hline $\begin{array}{l}\text { London Crown Hotel } \\
\text { Paddington }\end{array}$ & London & UK & 95 & $22,410,000$ & 235,900 & London Town Hotels & Undisclosed \\
\hline Ramada Plaza Regent's Park & London & UK & 377 & $97,110,000$ & 257,600 & UK Investor & Jarvis Hotels \\
\hline
\end{tabular}

Source: HVS International 
Table 2: Selected European portfolio hotel transactions 2004

\begin{tabular}{|c|c|c|c|c|c|c|}
\hline Portfolio & Country & $\begin{array}{l}\text { Number of } \\
\text { properties }\end{array}$ & $\begin{array}{l}\text { Number of } \\
\text { rooms }\end{array}$ & $\begin{array}{l}\text { Sale price } \\
\boldsymbol{\epsilon}\end{array}$ & $\begin{array}{l}\text { Price per room } \\
\epsilon\end{array}$ & Buyer \\
\hline Queens Moat House & UK & 4 & 408 & $57,200,000$ & 140,200 & Pederson Group \\
\hline 3 Accor Properties & UK & 3 & 412 & $57,200,000$ & 138,800 & Herax Property Fund \\
\hline Savoy Group & UK & 4 & 720 & $1,130,000,000$ & $1,569,444$ & Quinlan Group \\
\hline 8 Travelodges & Ireland & 8 & 520 & $22,150,000$ & 42,600 & Smorgs Ltd \\
\hline 5 Barcelo Hotels & Spain & 5 & 1,145 & $186,000,000$ & 162,400 & Barcelo Hotels \\
\hline $\begin{array}{l}\text { Citadines - remaining } \\
50 \% \text { stake }\end{array}$ & Europe & 46 & 5,100 & $74,300,000$ & 14,600 & Ascott Group \\
\hline Premier Lodge & UK & 131 & 9,000 & $730,000,000$ & 81,100 & Whitbread \\
\hline Paramount Hotel Group & UK & 16 & 2,540 & $320,000,000$ & 126,000 & Dawnay Day/Shore Capital \\
\hline Queens Moat Houses plc & $\begin{array}{l}\text { UK, } \\
\text { Netherlands, } \\
\text { Germany }\end{array}$ & 89 & $\mathrm{~N} / \mathrm{A}$ & $800,000,000$ & $\mathrm{~N} / \mathrm{A}$ & Goldman Sachs, Whitehall Fund \\
\hline
\end{tabular}

Source: HVS International

Notable single-asset deals in 2004 so far include the 360-room Radisson SAS Manchester Airport Hotel sold to German fund DIFA for approximately $€ 75 \mathrm{~m}$ ( $€ 209,000$ per room); the 98 -room Richemond Hotel in Geneva sold to Rocco Forte Hotels for approximately $€ 66 \mathrm{~m}$ ( $€ 674,000$ per room); and the Balzac and de Vigny luxury boutique hotels in Paris (for which HVS Hodges Ward Elliott was the selling agent) sold to JJW Hotels for $€ 53.5 \mathrm{~m}$ ( $€ 500,000$ per room) (see Table 1 ).

Significant portfolio transactions to date in 2004 include the sale of the Savoy Group of luxury hotels for approximately $€ 1.13 \mathrm{bn}$ $(€ 1.5 \mathrm{~m}$ per room); the sale of budget hotel chain Premier Lodge, comprising some 9,000 rooms, to Whitbread for approximately $€ 730 \mathrm{~m}(€ 81,000$ per room); and the recently approved acquisition by US investment bank Goldman Sachs of the UK-based hotel company Queens Moat Houses, with an enterprise value (including the company's debt) of nearly $€ 800 \mathrm{~m}$. See Table 2 for further details.

\section{FUNDING AND DEVELOPMENT}

Despite the ongoing challenges presented by the macroeconomic environment, hotel performances have been able to make some relatively healthy steps in 2004 , while other real estate classes such as offices have remained sluggish. In addition to this, the global stock market has continued to underperform, and inflation has remained low which has made higher risk asset classes such as hotels an increasingly attractive investment option to investors.

The pool of capital available to hotel investments is widening as more and more non-traditional hotel investors are seeking to diversify and broaden their interests. This has resulted in an explosive trend in equity capital investment, in the form of private equity and German and American funds, which is expected to continue into the foreseeable future.

At the same time, hotel operators are seeking to optimise their portfolios and boost share prices by disposing of their property 


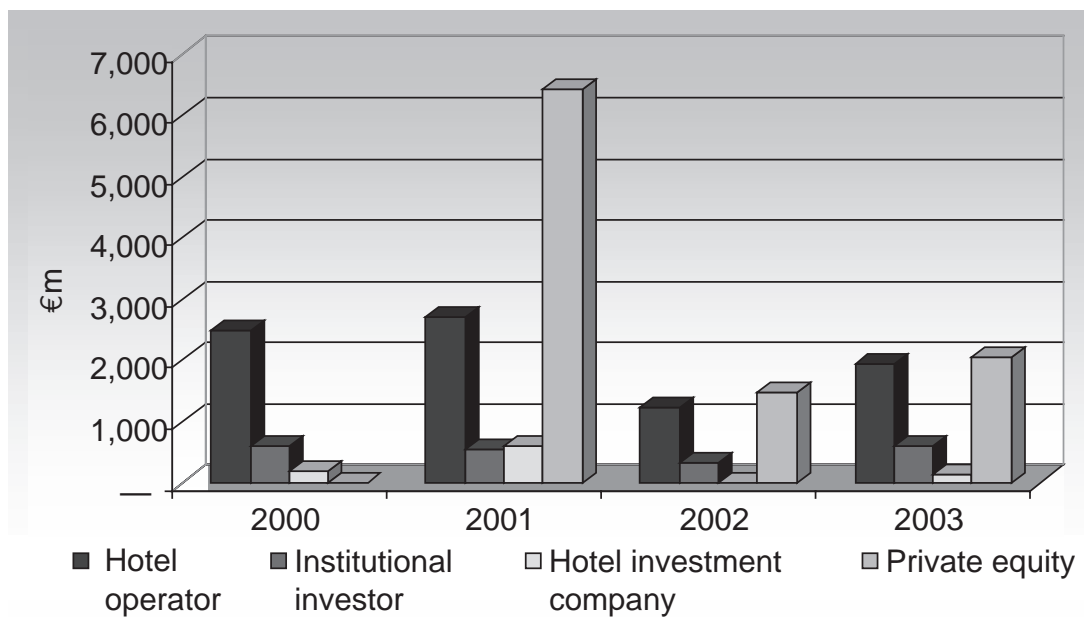

Figure 3: Total hotel investment by buyer category (by transaction volume) 2000-2003

assets. Earlier in the year the InterContinental Hotels Group, for example, announced its intention to dispose of 20 InterContinental and former Posthouse hotels. This is an increasingly prominent trend which is moving away from the tradition of direct investment by hotel operators into their hotel assets. Evidence for the splitting of real estate from management of operations was again confirmed more recently when Dawnay Shore Hotels was set up by two investment houses (Dawnay Day and Shore Capital) to purchase the Paramount Hotel Group for $£ 215 \mathrm{~m}$.

While hotel operators are currently selling more assets than any other hotel-owning group, they have also remained active buyers in an effort to achieve consolidation and a more dominant global presence. Sale and leaseback purchases have provided hotel operators with an innovative means to finance greater brand recognition in this respect. Although sale and leaseback deals in 2003 were less prominent than in previous years, it is thought that in the short to medium term this method of raising capital for expansion will remain buoyant. Indeed, in July 2004 Travelodge announced its intention to strike a sale and leaseback deal on 136 of its hotels in the UK. Travelodge intends to take leases of either 25 or 35 years on each property and hopes to raise at least $£ 400 \mathrm{~m}$ from the deal, money which the company would use to speed up the roll-out of a portfolio that already numbers more than 240 hotels and to reduce its debt.

\section{CONCLUSIONS}

Looking to the future, it is the potential development of Americanstyle real estate investment trusts (REITs) in the UK which may not only prove to add value to hotel investments, but also shape the UK property market as a whole. Typically, a REIT is a listed or listable portfolio real estate investment vehicle that has to 
distribute a substantial proportion of its income to its shareholders in return for exemption from corporate and capital gains tax.

Benefits include improved liquidity and diversification, lower cost of capital and access to the wider capital markets to help finance acquisitions and developments. In the USA, where REITs originated, they have proven to be particularly suited to the hotel sector and remain popular to institutional investors who seek longer-term security and greater tax efficiency. The authors consider that REIT structures (or property investment funds - PIFs - as they will be known in the UK) would benefit the whole market but should work particularly well for UK provincial mid-market hotel groups which, regardless of the economic downturn, have remained resilient. But one hurdle which will need to be overcome first is to convince the UK government not to exclude hotels as an asset class within the proposed PIF scheme. Watch this space!

\section{References}

1. Deloitte and Touche (2004) Monthly Bulletin for Europe, Hotel Benchmark Survey, Deloitte and Touche, London, UK.

2. HVS International (2004) European Hotel Valuation Index, HVS International, London, UK.

3. HVS International (2003) European Hotel Transactions, HVS International, London, UK. 